\title{
Harbour porpoises (Phocoena phocoena) and minke whales (Balaenoptera acutorostrata) observed during land-based surveys in The Minch, north-west Scotland
}

\author{
SARAH J. DOLMAN ${ }^{1}$, NICOLA K. HODGINS ${ }^{1}$, COLIN D. MACLEOD ${ }^{2,3}$, GRAHAM J. PIERCE ${ }^{3}$ \\ AND CAROLINE R. WEIR ${ }^{3}$ \\ ${ }^{1}$ Whale and Dolphin Conservation, 38 St Paul Street, Chippenham, Wiltshire, SN15 1LJ, UK, ${ }^{2}$ GIS In Ecology, 120 Churchill Drive, \\ Broomhill, Glasgow, G11 7EZ, UK, ${ }^{3}$ School of Biological Sciences (Zoology), University of Aberdeen, Tillydrone Avenue, Aberdeen, \\ $\mathrm{AB} 24$ 2TZ, UK
}

\begin{abstract}
The waters off north-west Scotland are known to provide important habitat for the harbour porpoise (Phocoena phocoena) and the minke whale (Balaenoptera acutorostrata). Between October 2008 and April 2011, systematic land-based surveys were carried out to assess the seasonal occurrence, group size and group behaviours of both species in a study area located off Melvaig, near Gairloch. Data were collected on 47 separate days, with a total of 4543 minutes of survey effort (in sea states $\leq 3$ ) recorded during the spring months and 8204 minutes of effort during the autumn. A total of 189 sightings of marine fauna were recorded, comprising 126 cetacean sightings, 50 seal sightings and 13 sightings of basking sharks (Cetorhinus maximus). Six species of cetacean were identified, with most sightings comprising harbour porpoise $(N=72)$ or minke whale $(N=38)$. Harbour porpoise abundance was higher in autumn than in spring and there was a variation between years in numbers of minke whales sighted. In porpoises, sea state and cloud cover both influenced sightings and increasing sea state influenced survey area. Foraging behaviour was exhibited in $13 \%$ of harbour porpoise sightings and $34 \%$ of minke whale sightings. Results demonstrate a regular occurrence of harbour porpoises and minke whales in nearshore waters off Gairloch. Densities are comparable to boat surveys in the region and so support the use of land-based watches as a potential longer-term monitoring method for these species in coastal waters. Given the regular use of this area by these two European Protected Species, as well as the occurrence of a range of human activities potentially affecting them in the region, it may be appropriate to consider protecting this area for their conservation.
\end{abstract}

Keywords: land-based surveys, harbour porpoise, Phocoena phocoena, minke whale, Balaenoptera acutorostrata, The Minch, north-west Scotland

Submitted 3 April 2012; accepted 24 March 2013; first published online 9 May 2013

\section{INTRDDUCTIDN}

Land-based studies can be effective for determining occurrence, density, abundance and habitat use of cetaceans, quantifying spatiotemporal trends and environmental relationships in these parameters. They can be used to evaluate the consequences of threats (e.g. boat traffic) and informing conservation management strategies, as shown by many previous studies in the UK (Evans et al., 1996; de Boer et al., 2002; Calderan, 2003; Stockin et al., 2006; Weir et al., 2007; Pierpoint, 2008; Pierpoint et al., 2009; Weir, 2010; Deecke et al., 2011; Embling, 2011).

Land-based studies offer a cost-effective, non-invasive means of gathering data which does not cause disturbance or affect the behaviour of the study animals (e.g. Pierpoint et al., 2009; Archer et al., 2010). Long-term datasets from land-based observations can provide useful indications of changes in

Corresponding author:

S.J. Dolman

Email: sarah.dolman@wdcs.org population size and distribution (Durban et al., 2010; Pierce et al., 2010). However, care should be taken in interpretation of spatially restricted land-based data, since trends in site use may not reflect wider population trends (Evans \& Hammond, 2004; Pierpoint et al., 2009). Summaries of the advantages and disadvantages of shore-based watches are provided by Thompson et al. (2000) and Evans \& Hammond (2004).

Along the north-west coast of Scotland, several data sources are available regarding cetacean occurrence. Seabird and cetacean surveys of the Atlantic Frontier conducted by the Joint Nature Conservation Committee (JNCC) recorded 15 species of cetacean between 1979 and 1998 (Weir et al., 2001), including harbour porpoises, white-beaked dolphins and minke whales (Northridge et al., 1995). Regular surveys conducted from passenger ferries have identified varying habitat preferences of harbour porpoises in the waters of north-west Scotland (Bannon et al., 2006). Large scale population estimates resulted from two large-scale surveys for Small Cetacean Abundance in the North Sea and adjacent areas (SCANS) undertaken during 1994 (Hammond et al., 2002) and 2005, including The Minch (SCANS II, 2008). The JNCC and SCANS datasets have been combined with 
data collected over more restricted areas by the Sea Watch Foundation to complete the UK Cetacean Atlas (Reid et al., 2003). These and other smaller scale surveys have reported harbour porpoise as the most commonly encountered species, with year-round presence in The Minch (Booth, 2010; Embling et al., 2010). The west coast of Scotland also contains the highest densities of harbour porpoises in Europe (Booth, 2010). Scottish waters also accommodate a largely seasonal minke whale population (Gill, 1994), with minke whales reported between March and November (Macleod et al., 2004). Increasing numbers are documented in the autumn months, and this has been linked to changes in foraging techniques throughout this time period. Some individuals reside year-round (Macleod et al., 2004; Pierce et al., 2004; Clark et al., 2010). Habitat preferences have been identified for a number of species, including both harbour porpoise (Marubini et al., 2009) and minke whale, in the waters west of Scotland (MacLeod et al., 2007; Anderwald et al., 2012).

Greater knowledge of habitat use and the habitat preferences of the cetacean species inhabiting the waters off the north-west coast of Scotland is required in order to determine their likely interaction with, and the potential impacts of, a range of human activities known to occur in the area. Existing activities include fisheries, military activities, commercial aquaculture acoustic devices (CAADs), marine wildlife tourism and recreational tourism. Twice yearly, in spring and autumn, the NATO international military exercise Joint Warrior (JW) is carried out in The Minches. A typical JW exercise includes between 20 and 30 naval vessels, comprising both surface and sub-surface units. In addition, around 75 aircraft participate, representing a wide variety of air power capabilities (MOD, 2011). The exercises are traditionally concentrated off the northwest of Scotland where a freedom to manoeuvre in both deep and shallow water, coupled with a limited civilian population, air and sea traffic, offers excellent training opportunities (MOD, 2011).

This paper presents the results of systematic land-based surveys carried out to assess the seasonal occurrence, group size and group behaviours of harbour porpoises and minke whales off north-west Scotland during the spring and autumn seasons of 2008-2011. Surveys were timed to correspond with the JW exercise in The Minches. The surveys were carried out at times known to have military NATO exercises taking place, with surveys carried out before, during and after the military exercises in the first year only. As a result it was not possible to monitor disturbance impacts and the data should be caveated, as they may be affected by the military activities.

Variation in the temporal occurrence of each species with respect to sea state, group composition and predominant behaviours were analysed. We consider the implications of the occurrence of cetacean species within this coastal site to their conservation management within both Scottish and European waters. We also consider the methodologies used during other land-based surveys and evaluate the potential for comparisons amongst other field sites with regards to habitat use and associated management requirements.

\section{MATERIALS AND METHODS}

\section{Study area}

The study site was situated at Melvaig $\left(57^{\circ} 48.696^{\prime} \mathrm{N}\right.$ $05^{\circ} 49.346^{\prime} \mathrm{W}$ ), near Gairloch, on the north-west coast of mainland Scotland (Figure 1). This site overlooks the southern part of The Minch, with the entrance to Loch Gairloch located to the south and Loch Ewe to the north. The Island of Rona in the Inner Sound between Raasay and the Scottish mainland represented the southern limits of the study area, while the westward and northward view extended towards the Isles of Lewis and Harris.

The small area of The Minch that this survey covers is made up of shelf habitats and water depths varying from o to $50 \mathrm{~m}$. The wider Minch beyond the survey area reaches more than $130 \mathrm{~m}$ in depth.

The Minch is a tidally and topographically complex region, with three main water masses: (i) an inflow of Atlantic water travelling northwards from along the west coast of Ireland; (ii) Irish sea inflow through the North Channel between the Mull of Kintyre and Ireland; and (iii) coastal water with a lower salinity due to the high freshwater run-off from the mainland (Gillibrand et al., 2003). The Minch encompasses a range of sandy and gravelly seabeds.

\section{Data collection}

Dedicated land-based surveys were conducted during spring (April-May) and autumn (September-October) from October 2008 to April 2011.

Two experienced observers carried out visual watches in 30 min rotations, with a single observer on watch at a time. Continuous scans were conducted over a $140^{\circ}$ area of water (to the horizon or nearest coastline) using Nikon $7 \times 50$ hand-held binoculars with internal compass and reticles. Each scan took approximately ten minutes, sweeping across the site from south to north. The distance to the horizon (based on $20 \mathrm{~m}$ observation height) was calculated as approximately $16 \mathrm{~km}$, where:

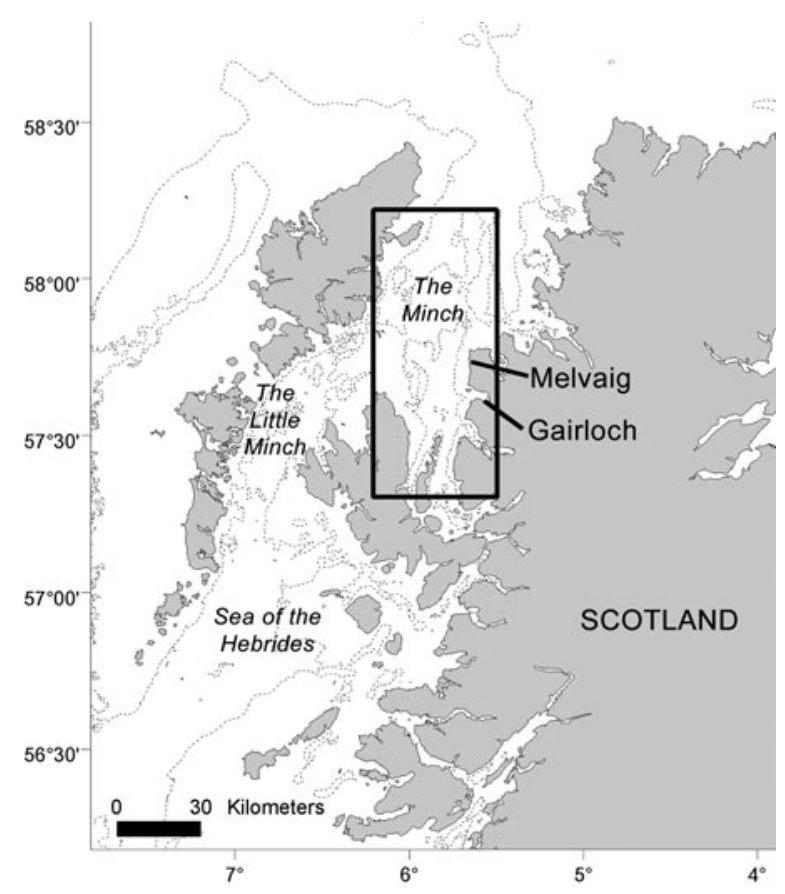

Fig. 1. Location of the study area (black box) and the land-based study site at Melvaig, near Gairloch, on the north-west coast of Scotland. 
$h=$ distance to horizon, which is approximately $h=R \times \tan$ $(\Phi)$

$R=$ radius of the earth $\approx 6,366 \mathrm{~km}$

$\Phi=$ angle between two radii of the earth, one passing through the observer and the other passing through any point on the horizon, as seen by the observer, which is $\cos ^{-1}\{(R /$ $R+v)\}$

$v=$ vertical height of the binoculars above sea level

$\Psi=$ angle of declination between the horizon and the sighting, which is $d \cdot \delta \quad d=$ the number of reticle divisions

$\delta=$ angle of declination between successive divisions on the reticle (radians) (Lerczak \& Hobbs, 1998).

Sweeps were made roughly once per $30 \mathrm{~min}$ with $40 \times 100$ long range observation binoculars (Big-Eyes) mounted on a tripod. Observations were conducted continuously only in sea state $\leq 3$, with good visibility of $\geq 1 \mathrm{~km}$. Environmental data (including sea state and cloud cover) were logged at 30 min intervals and whenever weather conditions changed.

A sighting was defined as each observation of an individual or a group of animals. For each sighting, the species identification, bearing, reticle, estimated distance by eye, school size, number of juveniles/calves, direction and any associated behaviour were recorded. All cetacean species were recorded and basking sharks (Cetorhinus maximus) and pinnipeds were additionally noted. Where group behaviours could be assigned, these were separated into the activity that more than $50 \%$ of the group were engaged in (Mann, 1999) and were defined as: (1) resting: when animals appeared motionless at the surface; (2) travelling: when they exhibited persistent directional movement in one direction; (3) foraging: indicated by lower directional movement with regular coordinated changes of direction, longer dives and less coordination and lunges; and (4) socializing: including breaching, surfing, high-speed movement and body contact with other animals (including sexual).

Big-Eyes were used for species identification where necessary. Care was taken to avoid repeated counts of the same individuals.

\section{Data analysis}

All cetaceans were recorded to the lowest taxonomic level possible, and only confirmed species sightings were used in the following analyses.

In order to assess changes in the occurrence of harbour porpoises and minke whales, a relative abundance value was recorded by calculating the number of sightings per $60 \mathrm{~min}$ search time. The detection rate of some cetaceans is known to be impacted by sea state and this is particularly true of harbour porpoises (Clarke, 1982; Palka, 1996). Consequently, data analysis commenced with an initial assessment of whether sea state impacted the dataset and needed to be accounted for. However, for harbour porpoises, there was a concern that, as small cetaceans, their detectability at sea state 2 would be lower than at sea states 0 and 1 . Thus a second measure of relative abundance was calculated for this species based on the area searched per hour of survey effort. For each scan the total area of sea searched was calculated by creating a circular buffer centred on the viewing point and clipping it to remove all areas of land before calculating the area of the remaining portion. The radius of this circular buffer for each sea state was determined by creating a cumulative curve of the number of porpoises recorded at everincreasing distances from the viewing point. In theory, such a curve should consist of a more or less straight line. However, in practice, at some distance this curve will change to approach an asymptote. This inflection point represents the threshold at which the detectability starts to decline due to the effect of distance, and therefore is the radius of the buffer for a specific sea state. Based on this analysis, the occurrence of harbour porpoises for any specific period of time was calculated by dividing the number of porpoises seen within the buffer area for each scan by the total area of all the buffers and dividing by six (the number of scans per hour). This produced a measure of porpoise occurrence with the units porpoises per $\mathrm{km}^{2}$ surveyed per hour that corrected for the fact that porpoises are detectable over a shorter distance at higher sea states that could be used as an index of the relative occurrence of harbour porpoise in the study area.

Despite the fact that this measurement reflects a measure of harbour porpoise density per $\mathrm{km}^{2}$ surveyed in a given time period, it will be referred to as the relative abundance index. This is because within cetacean research, the term relative abundance is commonly used to refer to any measure of occurrence that has been corrected for survey effort, regardless of whether it is a true measure of abundance or a density measurement.

Relative abundance indices were calculated for harbour porpoises and minke whales using both SPUE and individuals per unit effort (IPUE), the latter defined as the number of individuals recorded per $60 \mathrm{~min}$ search time. Both provide an index of relative abundance (Northridge et al., 1995; Reid et al., 2003; Weir et al., 2007). The SPUE and IPUE were visually compared across seasons and years to determine temporal occurrence of cetaceans within the study area.

To analyse temporal variation in group size between spring and autumn, Mann - Whitney $U$-tests were carried out using Minitab statistical software Version 15 (Minitab Ltd, 2007). A group is defined as animals actively swimming or foraging together. To further investigate temporal patterns of occurrence, numbers of individuals sighted per observation period were modelled using Generalized Additive Models (GAMs), assuming a Poisson distribution for the count data. The explanatory variables of interest were the time of day when observations started, month and year. Note that although data were collected during four calendar months, usually data collection was restricted to one month in spring and one in autumn, except in 2009, the only year in which the autumn survey started in September (but continued into October). In addition it was necessary to take into account observation duration (usually under $45 \mathrm{~min}$ but occasionally extending to $150 \mathrm{~min}$ ), sea state, cloud cover and possible differences between two observers. Initial data exploration suggested that these explanatory variables were only very weakly correlated with each other. The GAMs were fitted by backwards selection, sequentially removing non-significant variables until none remained or their removal would result in a poorer model fit (based on an F test). In principle the best model is the model with the lowest Akaike information criterion (AIC) value, which will normally contain only explanatory variables whose effects are individually significant. Final models were checked for the absence of influential data points and patterns in residuals and to confirm that the count data were a reasonable fit to a Poisson distribution 
(e.g. values of the dispersion parameter substantially greater than 1 indicate over-dispersion). The variables start time, observation duration, sea state and cloud cover were all treated as continuous and fitted as smoothers, setting the maximum number of 'knots' (k) to a value of 4 to constrain fitted relationships into relatively simple forms and thus avoid over-fitting. Observer, month and year were treated as categorical. Since the fitting procedure always compares categories with a single reference category, the final model was re-run several times with alternative coding of categories to ensure that all paired comparisons were completed.

Due to the relatively small data set $(\mathrm{N}=604$ watches $)$ compared to the large number of explanatory variables, interaction terms were not included in the model-fitting process. However, we tested whether the final models could be improved by adding interaction terms. In a GAM it is relatively straightforward to test for interactions between two variables but less so for three of more (except for categorical variables). If two or more variables are either categorical or fitted as a straight, their interactions can be simply specified within the model. If one variable of a pair is categorical and the other is fitted as a smoother, the significance of the interaction can be tested by fitting separate smoother for each value of the categorical variable, then comparing models with and without separate smoothers using an $\mathrm{F}$ test. If two variables are both fitted as smoothers, their interaction may be visualized by plotting a two-dimensional smoother and examining the 'smooth surface' for evidence of non-independence. However, visual examination is informative only if there is good coverage of parameter space and, since the twodimensional smoother captures both main effects and interactions and it may be necessary to constrain $k$ to avoid over-fitting, it is often difficult to objectively determine whether adding the interaction improves the model.

\section{RESULTS}

\section{Survey effort}

Survey effort was collected on 47 separate survey days (or part thereof) during the spring and autumn of 2008-2011. Five days (or part thereof) were conducted between 6 and 16 October 2008; 13 days between 9 and 29 May 2009; 13 days between 29 September and 19 October 2009; nine days between 11 and 23 April 2010; five days between 9 and 14 October 2010; and two days between 8 and 9 April 2011. In total, $212 \mathrm{~h} 27 \mathrm{~min}$ on-effort survey data were collected in Beaufort sea state $\leq 3,165 \mathrm{~h} 44 \mathrm{~min}(78 \%)$ of which occurred in sea states $\leq 2$ (Table 1 ). When accounting for distance (for harbour porpoise observations only) $38 \%$ and $62 \%$ of surveys were conducted in sea state 1 and 2 , respectively. The level of survey coverage varied between survey periods (Tables 1 and 2). More effort was collected in 2009 than in other survey years, and in autumn compared to spring.

\section{Species recorded}

A total of 189 sightings of marine fauna were recorded during the survey work (Table 3), the majority of which comprised cetaceans. The harbour porpoise was both the most frequently recorded species and the most numerous (Table 3). Minke whales, unidentified seals and basking sharks were also
Table 1. Survey coverage and sighting rates (SPUE and IPUE per $60 \mathrm{~min}$ ) calculated for harbour porpoise and minke whales recorded off Gairloch in each survey period, 2008-2011.

\begin{tabular}{|c|c|c|c|c|c|c|}
\hline \multirow[b]{2}{*}{ Survey period } & \multicolumn{2}{|c|}{ Survey effort (min) } & \multicolumn{2}{|c|}{$\begin{array}{l}\text { Harbour } \\
\text { porpoise } \\
\text { (sea state } \leq 2 \text { ) }\end{array}$} & \multicolumn{2}{|c|}{$\begin{array}{l}\text { Minke whale } \\
\text { (sea state } \leq 3 \text { ) }\end{array}$} \\
\hline & $\begin{array}{l}\text { Sea state } \\
\leq 2\end{array}$ & $\begin{array}{l}\text { Sea state } \\
\leq 3\end{array}$ & SPUE & IPUE & SPUE & IPUE \\
\hline Spring 2009 & 2120 & 2270 & 0.59 & 0.76 & 0.34 & 0.34 \\
\hline Spring 2010 & 1193 & 1583 & 1.06 & 1.71 & 0.00 & 0.00 \\
\hline Spring 2011 & 690 & 690 & 0.35 & 0.78 & 0.00 & 0.00 \\
\hline Spring total & 4003 & 4543 & 0.67 & 1.09 & 0.11 & 0.11 \\
\hline Autumn 2008 & 815 & 1323 & 0.00 & 0.00 & 0.50 & 0.77 \\
\hline Autumn 2009 & 2998 & 4004 & 0.04 & 0.08 & 0.15 & 0.16 \\
\hline Autumn 2010 & 2128 & 2877 & 0.62 & 2.26 & 0.08 & 0.08 \\
\hline Autumn total & 5941 & 8204 & 0.22 & 0.78 & 0.24 & 0.34 \\
\hline
\end{tabular}

regularly recorded, while four other cetacean species were positively identified only occasionally, most notably a sei whale (Figure 2).

\section{Sightings rates according to sea state and temporal period}

Harbour porpoise sighting rate (SPUE) per 60 min varied from o to 1.06, peaking during spring 2010 (Table 1 ) and from o to 0.05 when distance was incorporated, where area surveyed decreased with increasing sea state, with $10.98 \mathrm{~km}^{2}$ being surveyed and observations to $2743 \mathrm{~m}$ in sea state 1 and $3.53 \mathrm{~km}^{2}$ being surveyed and observations to $1616 \mathrm{~m}$ in sea state 2 . The IPUE peaked during the spring and autumn of 2010 . Porpoises were recorded in every study period except for autumn 2008, when relatively little survey effort occurred due to unfavourable sea states. There was high variability in SPUE and IPUE both within and between years and seasons.

The initial analysis of sighting rate (SPUE) versus sea state indicated that a marked decline in harbour porpoise detection occurred as sea state increased from o to 3 (Figure 3 ). Minke whale detection did not appear to be as adversely affected by the increase in sea state (Figure 3). GAM results for numbers of harbour porpoise seen per observation period confirmed a

Table 2. Survey coverage and sighting rates accounting for detectability radius (SPUE and IPUE per $60 \mathrm{~min}$ ) for harbour porpoise recorded off Gairloch in each survey period, 2008-2011.

\begin{tabular}{|c|c|c|c|c|c|c|}
\hline \multirow[b]{2}{*}{ Survey period } & \multicolumn{2}{|c|}{ Survey effort (min) } & \multicolumn{2}{|c|}{$\begin{array}{l}\text { Harbour } \\
\text { porpoise } \\
\text { (sea state 1) }\end{array}$} & \multicolumn{2}{|c|}{ (Sea state 2 ) } \\
\hline & $\begin{array}{l}\text { Sea state } \\
\leq 1\end{array}$ & $\begin{array}{l}\text { Sea state } \\
\leq 2\end{array}$ & SPUE & IPUE & SPUE & IPUE \\
\hline Spring 2009 & 1336 & 2120 & 0.45 & 0.49 & 0.32 & 0.47 \\
\hline Spring 2010 & 1492 & 1193 & 0.56 & 0.97 & 0.10 & 0.10 \\
\hline Spring 2011 & 320 & 690 & 0.38 & 1.13 & 0.16 & 0.32 \\
\hline Spring total & 3148 & 4003 & 0.46 & 0.86 & 0.19 & 0.30 \\
\hline Autumn 2008 & 65 & 815 & 0.00 & 0.00 & 0.00 & 0.00 \\
\hline Autumn 2009 & 250 & 2998 & 0.00 & 0.00 & 0.06 & 0.13 \\
\hline Autumn 2010 & 300 & 2128 & 2.40 & 9.80 & 0.40 & 0.94 \\
\hline Autumn total & 615 & 5941 & 0.80 & 3.27 & 0.16 & 0.36 \\
\hline
\end{tabular}


Table 3. Number of marine species and individuals identified during the study period from land-based observations at Gairloch in north-west Scotland, 2008-2011.

\begin{tabular}{lcc}
\hline Species & Observations & Individuals \\
\hline Sei whale, Balaenoptera borealis & 1 & 1 \\
Minke whale, Balaenoptera acutorostrata & 38 & 45 \\
Killer whale, Orcinus orca & 1 & 3 \\
Bottlenose dolphin, Tursiops truncatus & 3 & 39 \\
Common dolphin, Delphinus delphis & 1 & 1 \\
Harbour porpoise, Phocoena phocoena & 72 & 161 \\
Unidentified cetacean & 10 & 39 \\
Grey seal, Halichoerus grypus & 3 & 3 \\
Unidentified seal & 47 & 56 \\
Basking shark, Cetorhinus maximus & 13 & 19 \\
Total & 189 & 367 \\
\hline
\end{tabular}

clear and linear decline in the number of porpoises sighted with increasing sea state $(\mathrm{df}=1, P<0.0001)$, also a weak decline with increasing cloud cover over the range o to $3 / 8$ $(\mathrm{df}=2.155, P=0.0059)$. There was a weak observer effect (observer two saw more porpoises, $P=0.0113$ ) and an effect of observation duration (a decline in numbers sighted for observation periods $>30 \mathrm{~min}$, possibly indicative of observer fatigue $(\mathrm{df}=1.885, P=0.0078)$. Temporal trends in the data were as follows: numbers sighted rose from an early morning low to a clear peak just after 11.00 hrs but then declined again until around 16.00 hrs. Inclusion of month improved the model (F test, $P=0.0037$ ) with lower sightings in May compared to October, $P=0.0150$ ). There was no significant difference between years. The model explained $25.5 \%$ of deviance (AIC $=669.86)$ and was a reasonable fit; smoothers are illustrated in Figure 4.

Exploration of interactions indicated significant interactions between month and start time, month and duration of observations, and observer and sea state. Two-dimensional smoothers were either difficult to visualize due to poor coverage of parameter space (e.g. start hour versus duration) or showed an apparent lack of interaction (e.g. cloud cover versus sea state). Including the three significant interactions in the previous final model increased \% deviance explained to $36.6 \%(\mathrm{AIC}=619.23)$. Visual examination of smoothers (not shown) indicated that the decreased probability of

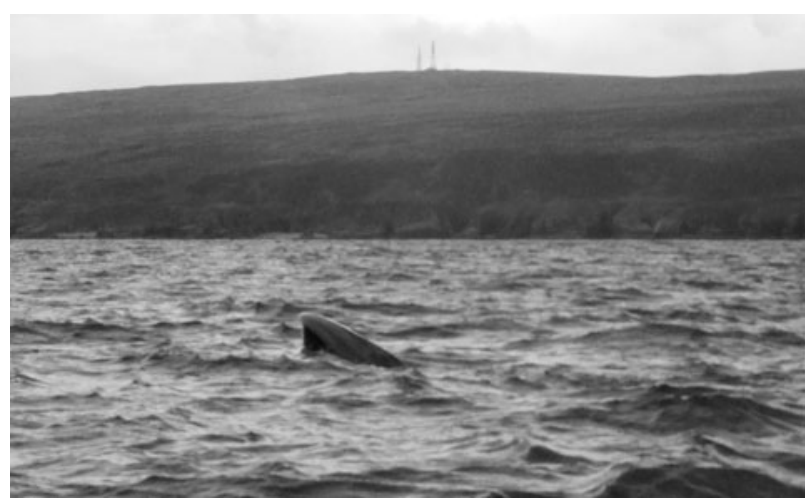

Fig. 2. The sei whale observed during land-based watches on 14 October 2008 and photographed from a marine wildlife watching vessel (photograph Elizabeth Ingram). This animal was identified as a sei whale based on its large size, tall visible blow, dark coloured baleen plates and the shape of the rostrum which comprised the downturned tip characteristic of sei whales (Tom Jefferson, personal communication).

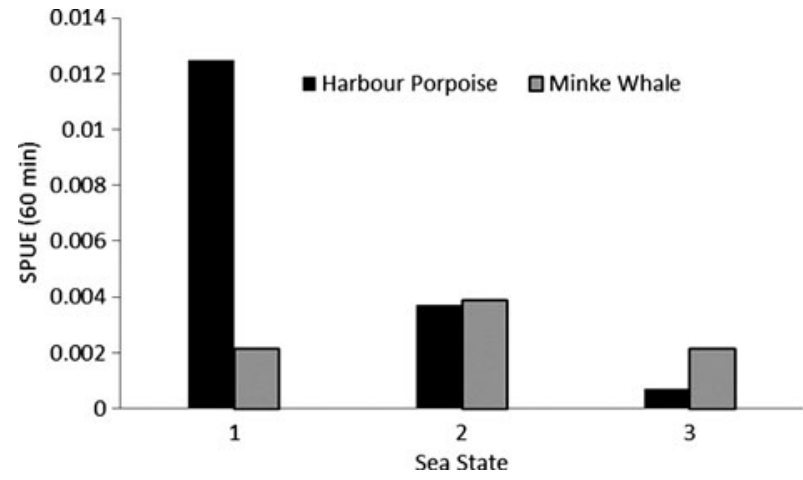

Fig. 3. Sighting rates (SPUE) of harbour porpoises and minke whales against Beaufort sea state during the study period from land-based observations at Gairloch in north-west Scotland, 2008-2011.

seeing a porpoise for longer observation periods was most evident in May. A significant effect of cloud cover was evident in May and October, with a marked decline in sighting probability over the range o to 3 seen only in October. Finally, the decline in probability of seeing a porpoise at higher sea states was more marked in observer two.

Generalized Additive Model results for numbers of minke whales seen per observation period, as expected given the relative ease of detection for this species revealed case effect of sea state, cloud cover or observer identity. Although significantly higher numbers were sighted in 2008 than in 2009 or $2010(P$ $<0.0001$ in both cases) and in September as compared to October $(P<0.0001)$ and May $(P=0.0002)$, overall neither year nor month effects were significant (and it should be noted that coverage of different months differed between years, making these effects difficult to evaluate). However, presence of both terms significantly improved the model according to $\mathrm{F}$ tests and they were therefore retained in the final model. There was a decline in numbers sighted for longer observation periods $(\mathrm{df}=1, P<0.0001)$. Sightings showed a peak between $11.00 \mathrm{hrs}$ and $12.00 \mathrm{hrs}(\mathrm{df}=2.63$, $P<0.0001)$. The model explained $27.3 \%$ of deviance $(\mathrm{AIC}=291.67)$ and smoothers are illustrated in Figure 5.

In the case of the minke whale model, not all interactions could be determined due to insufficient data. However, there were significant interactions between start hour and year and between duration and month. Including these interactions in the previous final model increased deviance explained to $39.3 \%$ (AIC $=278.29$ ). Smoothers (not shown) indicated that the probability of seeing a minke whale peaked between $11.00 \mathrm{hrs}$ and $12.00 \mathrm{hrs}$ in 2008 but at around $14.00 \mathrm{hrs}$ in 2009, while the decline in numbers sighted with increased observation duration was evident only in September.

\section{Group size}

The majority of harbour porpoise sightings (49\%) comprised single individuals. Twenty-six per cent of sightings comprised pairs of animals and $7 \%$ comprised groups of three or four animals. The largest aggregations of eight animals were observed on two separate occasions. The mean group size recorded during harbour porpoise sightings was significantly higher (Mann-Whitney $U$-test, $\mathrm{W}=1316.0, P<0.0001$ ) during autumn $(\bar{x}=3.50, \mathrm{SD}=2.14, N=26)$ than during spring $(\bar{x}=1.52, \mathrm{SD}=0.94, N=46)$. 
A

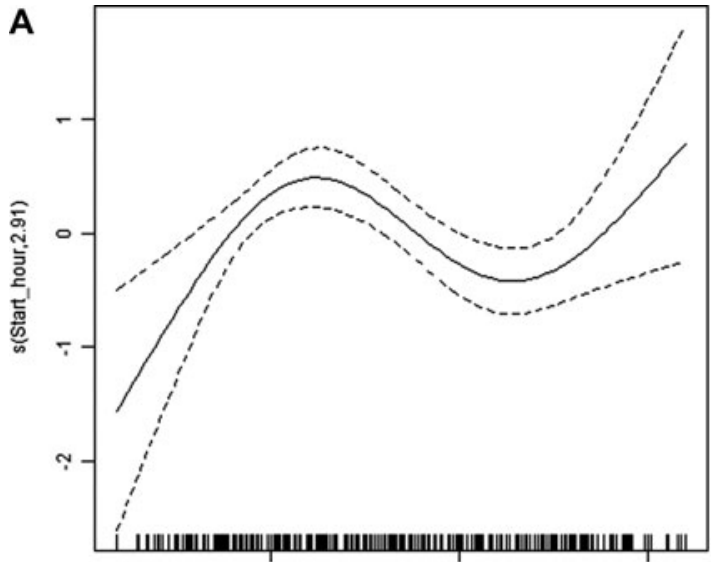

10

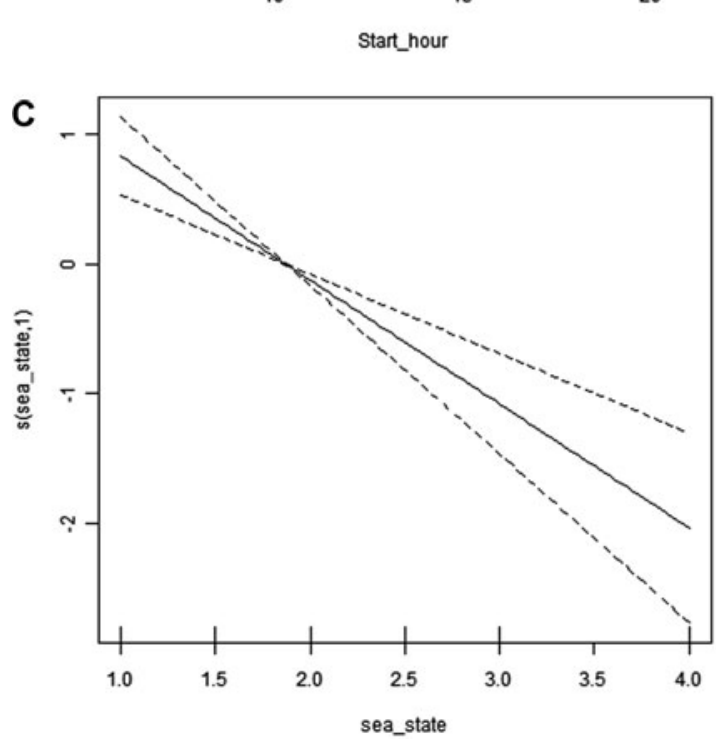

B
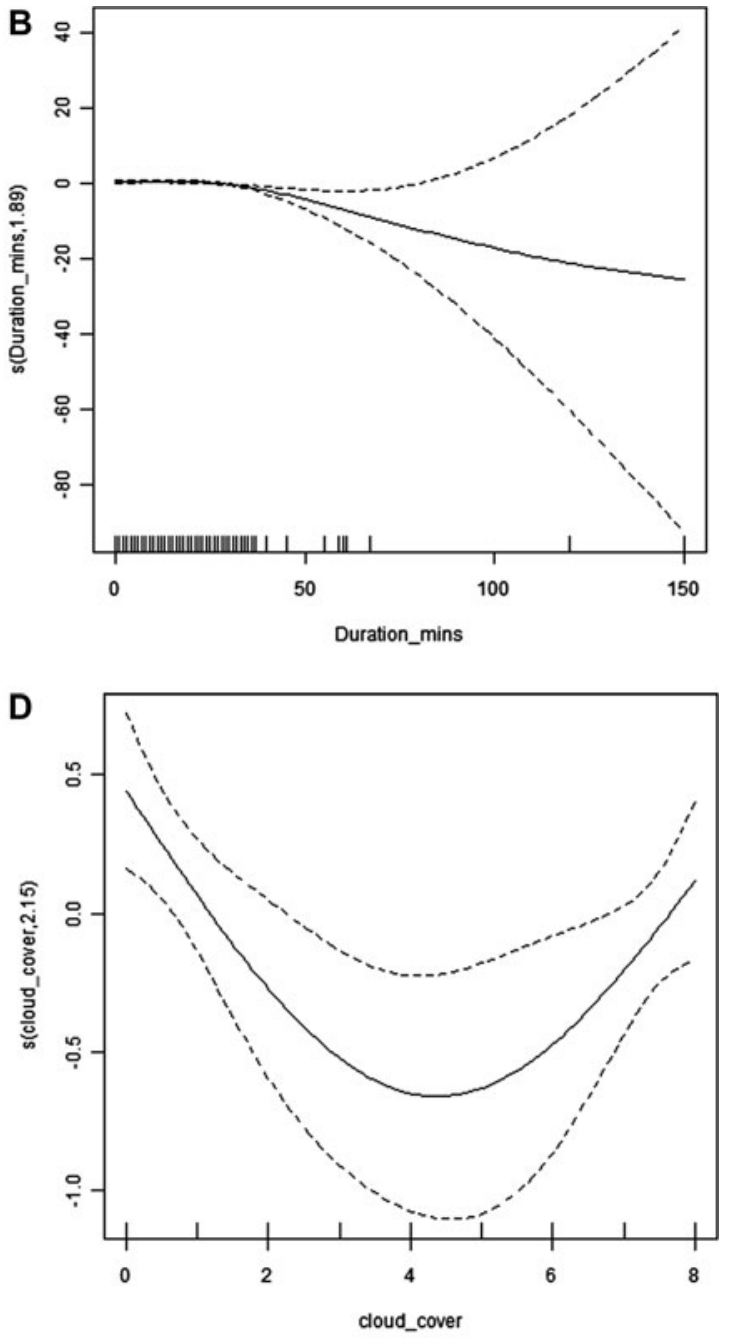

Fig. 4. Results from Generalized Additive Models fitted to numbers of porpoises sighted: smoothers for effects of (A) start hour of observation, (B) duration of observation, (C) sea state and (D) cloud cover. Dotted lines are $95 \%$ confidence limits; where a horizontal line could be drawn within the $95 \%$ confidence limits the explanatory variable can be said to have no significant effect over the relevant range of values.

Minke whales were observed only as solitary individuals during spring $(N=13)$. Groups of between one and four animals were recorded in autumn, with a mean of 1.28 animals ( $\mathrm{SD}=0.68, N=25)$. Overall, most sightings $(87 \%)$ comprised individual animals, with $11 \%$ comprising pairs and a single sighting of four animals.
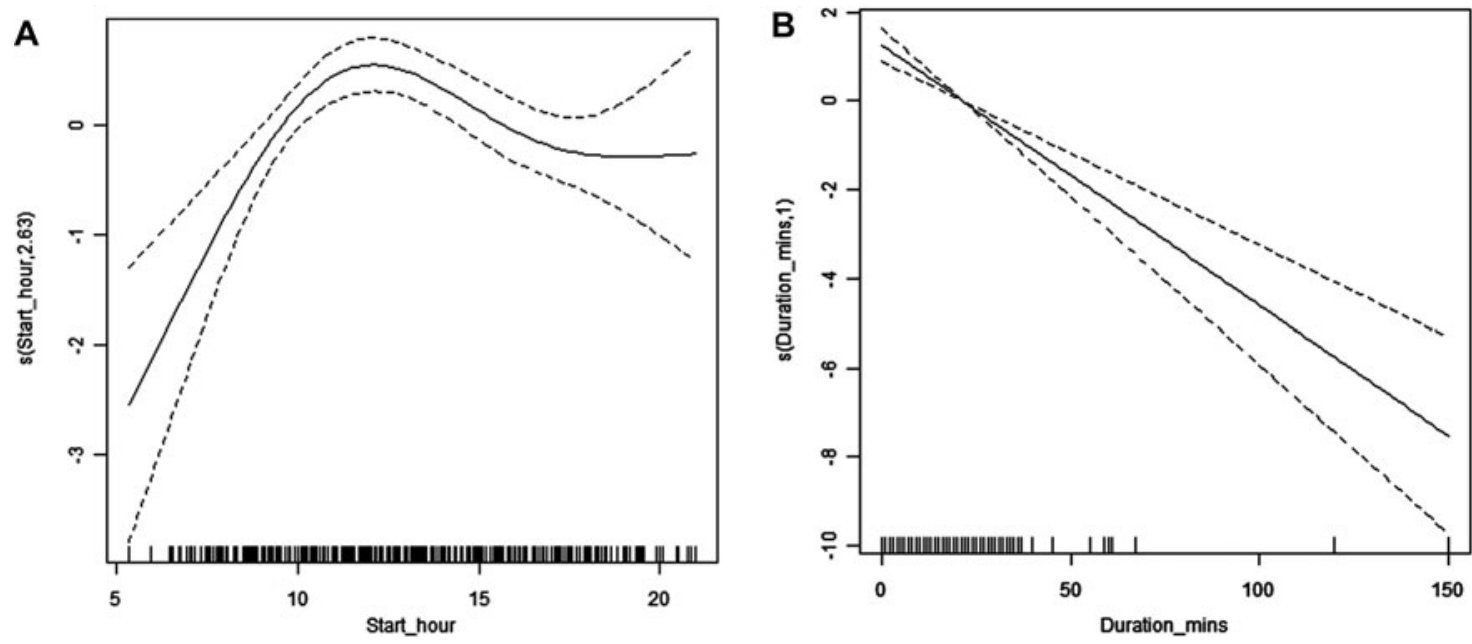

Fig. 5. Results from Generalized Additive Models fitted to numbers of minke whales sighted: smoothers for effects of (A) start hour of observation and (B) duration of observation. 


\section{Behaviour}

Behaviour was assigned to $67(95.7 \%)$ porpoise sightings and $31(81.6 \%)$ minke whale sightings. For both species, travelling was the most frequently recorded behaviour, being noted for $80 \%$ of porpoise sightings and $47 \%$ of minke whale sightings.

Foraging behaviour was exhibited in $13 \%$ of harbour porpoise sightings and $34 \%$ of minke whale sightings. All sightings of pairs or groups of minke whales $(N=13)$ involved animals engaged in foraging behaviour.

\section{DISCUSSIDN}

These data demonstrate a regular occurrence of harbour porpoises and minke whales in the coastal waters of The Minch off Gairloch, and support existing data suggesting that the shelf waters along the west coast of Scotland hold some of the highest harbour porpoise densities in Europe (Hammond et al., 2002; Evans \& Wang, 2008; SCANS-II, 2008; Booth, 2010). The data also demonstrate the value of the area for a diversity of other marine species, including seals and basking sharks.

Observations in spring 2009 were undertaken during May, whilst in 2010 and 2011 they were undertaken in April. This may explain why minke whales were only seen during the first years' spring observations, as the seasonally resident animals (Gill et al., 2000) are known to occur in coastal waters off the west coast to feed between May and October (Northridge et al., 1995). Our observation periods in April during 2010 and 2011 may have taken place before minke whales had arrived to forage in The Minch. Although seasonal survey coverage was limited in all years, data were adequate to confirm that porpoise abundance index was higher in autumn than in spring, as well as to highlight the greater variation between years seen in numbers of minke whales sighted. Other trends were clearly related to detection of animals by observers. In porpoises, sea state and cloud cover both influenced sightings and there was also a detectable observer effect. Detection of both species seemed to decline for longer observation periods, possibly due to observer fatigue or a subconscious tendency to observe for longer if nothing was seen.

Group sizes of porpoises and minke whales recorded at Gairloch were comparable with those observed during landbased surveys from other identified 'hot spots' (Calderan, 2003; Pierpoint et al., 2007; Goodwin, 2008; Pierpoint, 2008; Weir, 2008). These data support a feeding occurrence of groups of minke whales in autumn (Macleod et al., 2004). Stomach contents from ten minke whales that stranded around the Scottish coastline comprised mainly sandeels (Ammodytidae, around two-thirds of the diet by number or weight) and clupeids (herring Clupea harengus and sprat Sprattus sprattus) (Pierce et al., 2004).

\section{Comparison with other areas of the UK}

\section{SPUE/IPUE}

No standardized method for analyzing land-based sightings rates of cetaceans currently exists. Direct comparisons between this study and results of previous studies may not be appropriate in all cases, but future standardization of methods between sites would facilitate comparisons across the UK, and have useful management implications. Accounting for reduced survey area in increasing sea state is not commonly reported but would assist with understanding densities more accurately, including in calm versus tidally active areas. Comparing the results of this study with those in other areas must be caveated due to varying study periods, different environments, and different sea states, especially in relation to harbour porpoises.

Sightings rates of harbour porpoises off Aberdeenshire on the east coast of Scotland were highest in August (0.97 per $60 \mathrm{~min}$ ) and September (0.94 per $60 \mathrm{~min}$ ), but no porpoises were observed during land-based surveys conducted in October (Weir et al., 2007). These figures are higher than we obtained off Gairloch, except in spring 2010, when our sightings rate was 1.06. Relative abundance of harbour porpoise in Galway Bay from land-based surveys was greatest from Black Head (2.12 sightings per $60 \mathrm{~min}$ ) (Berrow, 2009). Harbour porpoise sightings per $60 \mathrm{~min}$ from Bardsey Island in North Wales between 1997 and 2000 were 0.23 , $0.29,0.41$ and 0.32, respectively (de Boer et al., 2002). Pierpoint (2009) used the proportion of positive scan samples to investigate a high-energy, known foraging ground in South Ramsay Sound in South Wales, where porpoises were present in $46 \%$ of scan samples during the ebb phase, and only $5 \%$ of samples in the flood phase at South Sound.

More commonly, relative abundance (number of porpoises per $100 \mathrm{~km}$ ) has been calculated from boat-based surveys. Whilst it is not appropriate to directly compare land- and boat-based studies, results of the present study are consistent with previous boat-based studies in that they identify high densities of porpoises (Goodwin \& Speedie, 2008; Booth, 2010) and minke whales (Macleod et al., 2004) in The Minch.

Minke whales observed within the southern Moray Firth peaked from July to August (Robinson et al., 2009). Minke whales were also observed off the Aberdeenshire coast in August (Weir et al., 2007) and sightings rates overall (0.02 per 60 min between May 1999 and October 2001) were lower than in our study area (0.19 per 60 min over the study period). Sighting rates of minke whales have increased dramatically in west, north and east Scotland since the early 1990 (Evans et al., 2003) although they were absent from the Southern Outer Moray Firth in 2004 (Tetley et al., 2008). On the west coast, however, minke whale numbers were unusually low in 2005 and 2006 (Anderwald \& Evans, 2007; Stevick, 2007), where local prey shortages have been reported to be responsible (Anderwald \& Evans, 2007). Yet at this time, minke whale observations were at their recorded annual highest in the Moray Firth (Tetley, 2010). Previous analysis has shown an alternate pattern in sightings rates between the west and east coast and existing data in recent years could ascertain the likelihood of that trend continuing (M. Tetley, personal communication). Our dataset could be usefully incorporated into this wider analysis.

This study supports previous work that identifies high sightings rates of both harbour porpoises and minke whales in The Minch, compared to other regions known to be important for these species. Previous studies have identified that the habitat including both static bathymetric (depth, slope, sediment type) and persistent hydrographic variables (tidal current, temperature) are important in determining their distribution (Baumgartner, 2008; Tetley et al., 2008; Marubini et al., 2009; Embling et al., 2010). 


\section{Management implications}

Military activities, commercial aquaculture acoustic devices (CAADs), commercial marine wildlife watching, recreational tourism and fisheries activities are human activities in The Minch that may be expected to impact on cetaceans. Evidence exists of short-term impacts on cetaceans from each of these activities in this region (Parsons et al., 2000; Bejder et al., 2006; Lusseau \& Bejder, 2007; Booth, 2010; Dolman \& Simmonds, 2010). Marine renewable energy developments (wind, wave and tidal) are planned for the west coast of Scotland, and tidal energy has been identified as most likely to occur near Gairloch and more widely in The Minch ${ }^{1}$. Little field research has been done so far to understand the potential impacts of tidal development on the variety of coastal cetaceans likely to be encountered in Scottish waters, although collision concerns have been raised with regard to harbour porpoises (Carter, 2008). The potential impact on our dataset from sound generated during Exercise JW is unknown. The British Underwater Test and Evaluation Range (BUTEC) off the north-east coast of Raasay and approximately 20 nautical miles from the study area is operational year-round. BUTEC is a passive array of sea-bed mounted hydrophones used to monitor active acoustic emissions of submarines. No impact studies or Environmental Impact Assessments (EIAs) of military exercise area usage have taken place of which the authors are aware.

Monitoring of cetacean species is important for meeting legal obligations, establishing appropriate conservation objectives and priorities, assessing and mitigating anthropogenic impacts and measuring the effectiveness of management plans. The Scottish Government is required to meet its national and international commitments to designate an ecologically coherent network of Marine Protected Areas (MPAs) by 2012. The MPA network should be supported by the wider system of marine planning which will be delivered through the framework of the Marine (Scotland) Act 2010. It is anticipated that cetaceans will be designated features within the new MPAs, and the sites will be managed to meet their conservation needs.

Porpoises and minke whales are listed as 'Priority Marine Features' in wider seas measures in the Scottish marine planning process and as a nationally important species, and given the high densities recorded in The Minch, both should be fully considered for regional protection. Harbour porpoises are one of the two cetacean species for which member states are required to establish Special Areas of Conservation (SACs) (EU Council Directive, 92/43/ECC, 1992). Neither the Scottish nor the UK government has designated any SACs for their protection, despite considerable scientific support for them, including in The Minch (Booth, 2010; Clark et al., 2010; Embling et al., 2010; Evans \& Prior, 2011).

Minke whales have been identified as a 'Search Feature' and as a result should drive the Scottish MPA designation process. The value of the northern part of The Minch has been recognised for minke whales (Weir, in press). The Minch seems to be of year-round importance for porpoises and seasonally for minke whales and this dataset, combined with others from that area, demonstrate the region's suitability for consideration of spatial protection. More data are always needed, especially in the other seasons and in the absence of NATO

${ }^{1} \mathrm{JNCC} / \mathrm{NE}$ Marine Conservation Zone (MCZ) interactive map project: http://www.mczmapping.org/ exercises; however this should not impede immediate protection efforts. MPAs may offer useful conservation benefits for these species in The Minch region. The management of any proposed MPA should take account of the human activities in Gairloch and the surrounding region, including but not limited to military exercises and use of the BUTEC range off Raasay, to enable adequate consideration of cumulative and synergistic impacts. Understanding and effectively mitigating these potential impacts should be a priority given the listing of cetaceans as European Protected Species requiring strict protection under the EU Habitats Directive.

\section{ACKNOWLEDGEMENTS}

Thanks to Pine Eisfeld, Lindsay Roberts and Mike Tetley for valuable comments on a draft of the manuscript. Thanks to Nick Davies from Hebridean Whale Cruises and Elizabeth Ingram for photograph to confirm the sei whale sighting. Field equipment was provided by the Whale and Dolphin Conservation (WDC). We would also like to thank the two anonymous referees for their constructive comments.

\section{FINANCIAL SUPPORT}

Funding was kindly provided by Okeanos, adoption.co.uk, BBC Wildlife Fund and Project Aware.

\section{REFERENCES}

Anderwald P., Evans P.G.H., Dyer R., Dale A., Wright P.J. and Hoelzel R.A. (2012) Spatial scale and environmental determinants in minke whale habitat use and foraging. Marine Ecology Progress Series 450, 259-274.

Anderwald P. and Evans P.G.H. (2007) Minke whale populations in the North Atlantic-an overview with special reference to UK waters. In Robinson K.P., Stevick P.T. and MacLeod C.D. (eds) An integrated approach to non-lethal research on Minke whales in European waters. European Cetacean Society, Special Publication Series, Issue 47 , pp. $8-13$.

Archer F.I., Mesnick S.L. and Allen A.C. (2010) Variation and predictors of vessel-response behaviour in a tropical dolphin community. Report to NOAA, NOAA-TM-NMFS-SWFSC-457. 60 pages. Available at: http://swfsc.noaa.gov/publications/TM/SWFSC/NOAA-TM-NMFSSWFSC-457.pdf (accessed 4 April 2013).

Bannon S.M., MacLeod C.D. and Pierce G.J. (2006) Spatio-temporal variations in habitat preferences of harbour porpoises in the waters northwest of Scotland. Abstract presented at the 2oth Annual Conference of the European Cetacean Society, Gdynia, Poland.

Baumgartner N. (2008) Distribution, diving behaviour and identification of the north Atlantic minke whale in northeast Scotland. MPhil thesis. University of Aberdeen, School of Biological Sciences (Zoology).

Bejder L., Samuels A., Whitehead H. and Gales N. (2006) Interpreting short-term behavioural responses to disturbance within a longitudinal perspective. Animal Behaviour 72, 1149-1158.

Berrow S. (2009) Review of special areas of conservation for harbour porpoise and bottlenose dolphins in Ireland. Irish Whale and Dolphin Group Report.

Boer M. de, Morgan-Jenks M., Taylor M. and Simmonds M.P. (2002) The small cetaceans of Cardigan Bay. British Wildlife 246-255. 
Booth C.G. (2010) Variation in habitat preference and distribution of harbour porpoises west of Scotland. PhD thesis: Scottish Oceans Institute, Sea Mammal Research Unit, University of St Andrews, St Andrews, UK.

Calderan S. (2003). Fine scale temporal distribution by harbour porpoise (Phocoena phocoena) in North Wales: acoustic and visual survey techniques. MSc thesis. University of Wales, Bangor, UK.

Clarke R. (1982) An index of sighting conditions for surveys of whales and dolphins. Report of the International Whaling Commission, 32, 559-561.

Clark J., Dolman S.J. and Hoyt E. (2010) Towards marine protected areas for cetaceans in Scotland, England and Wales: a scientific review identifying critical habitat with key recommendations. Whale and Dolphin Conservation Society Report, Chippenham, UK.

Deecke V.B., Nykänen M., Foote A.D. and Janik V.M. (2011) Vocal behaviour and feeding ecology of killer whales Orcinus orca around Shetland, UK. Aquatic Mammals 13, 79-88.

Dolman S.J. and Simmonds M.P. (2010) Towards best environmental practice for cetacean conservation in developing Scotland's marine renewable energy. Marine Policy 34, 1021-1027.

Durban J., Lang A., Weller D., Rugh D., Hobbs R. and Perryman W. (2010) Comparing two methods of shore-based counts of eastern North Pacific gray whales. Paper presented to the International Whaling Commission, SC/62/BRG8.

Embling C.B. (2011). WDCS shorewatch data analysis. Internal report to the Whale and Dolphin Conservation Society. Available from the first author on request.

Embling C.B., Gillibrand P.A., Gordon J., Shrimpton J., Stevick P.T. and Hammond P.S. (2010) Using habitat models to identify suitable sites for marine protected areas for harbour porpoises (Phocoena phocoena). Biological Conservation 143, 267-279.

Evans P.G.H. and Prior J.S. (2011) Protecting the harbour porpoise in UK seas. We've identified a 'shadow list' of Natura 2000 sites under the EC Habitats Directive. WWF Report.

Evans P.G.H. and Hammond P.S. (2004) Monitoring cetaceans in European waters. Mammal Review 34, 131-156.

Evans P.G.H. and Wang J. (2008) Harbour porpoise spatial modelling to identify possible hotspots for marine protected areas. Proceedings of the ECS/ASCOBANS/ACCOBAMS workshop selection criteria for marine protected areas for cetaceans. European Cetacean Society's 21st Annual Conference, The Aquarium, San Sebastian, Spain, 22 April 2007. European Cetacean Society, pp. 44-49.

Evans P.G.H., Anderwald P. and Baines M.E. (2003) UK cetacean status review. Report to English Nature and Countryside Council for Wales. Sea Watch Foundation, Oxford

Evans P.G.H., Weir C.R. and Nice H.E. (1996) Temporal and spatial distribution of harbour porpoises in Shetland waters, 1990-1995. In European Research on Cetaceans-10: Proceedings of the tenth Annual Conference of the European Cetacean Society, Lisbon, Portugal, 1996. European Cetacean Society, pp. 234-237.

Gill A., Fairbairns B. and Fairbairns R. (2000) Photo-identification of the Minke whale (Balaenoptera acutorostrata) around the Isle of Mull, Scotland. Report to the Hebridean Whale and Dolphin Trust. Available at: http://www.whaledolphintrust.co.uk/cust_images/ research\%2opublications/MinkeWhalePhotoID-AlisonGill.pdf (accessed 4 April 2013).

Gill A. (1994) The photo-identification of the minke whale (Balaenoptera acutorostrata) off the Isle of Mull, Scotland. MSc thesis. University of Aberdeen, Aberdeen, UK.

Gillibrand P.A., Sammes P.J., Slesser G. and Adams R.D. (2003) Seasonal water column characteristics in the Little and North
Minches and the Sea of the Hebrides. I. Physical and chemical parameters. Fisheries Research Services Internal Report No. 08/03.

Goodwin L. and Speedie C. (2008) Relative abundance, density and distribution of the harbour porpoise (Phocoena phocoena) along the west coast of the UK. Journal of the Marine Biological Association of the United Kingdom 88, 1221-1228.

Goodwin L. (2008) Diurnal and tidal variations in habitat use of the harbour porpoise (Phocoena phocoena) in southwest Britain. Aquatic Mammals 34, 44-53.

Hammond P.S., Berggren P., Benke H., Borchers D.L., Collet A., Heide-Jørgensen M.P., Heimlich S., Hiby A.R., Leopold M.F. and Øien N. (2002) Abundance of harbour porpoises and other cetaceans in the North Sea and adjacent waters. Journal of Applied Ecology 39, $361-376$.

Lerczak J.A. and Hobbs R.C. (1998) Calculating sightings distances from angular readings during shipboard, aerial and shore-based marine mammal surveys. Marine Mammal Science 14, 590-598.

Lusseau D. and Bejder L. (2007) The long-term consequences of shortterm responses to disturbance experiences from whale-watching impact assessment. International Journal of Comparative Psychology $2007,228-236$.

MacLeod C.D., Bannon S.M., Brereton T. and Wall D. (2007) Using passenger ferries to study seasonal patterns of minke whale occurrence in NW Europe. In Robinson K.P., Stevick P.T. and MacLeod C.D. (eds) An integrated approach to non-lethal research on Minke whales in European waters. European Cetacean Society Special Publication, Issue 47 , pp. $8-13$

Macleod K., Fairbairns R., Gill A., Fairbairns B., Gordon J., Blair-Myers C. and Parsons E.C.M. (2004) Seasonal distribution of minke whales Balaenoptera acutorostrata in relation to physiography and prey off the Isle of Mull, Scotland. Marine Ecology Progress Series $277,263-274$

Mann J. (1999) Behavioural sampling methods for cetaceans: a review and critique. Marine Mammal Science 15, 102-122.

Marubini F., Gimona A., Evans P.G.H., Wright P.J. and Pierce G.J. (2009) Habitat preferences and interannual variability in occurrence of the harbour porpoise, Phocoena phocoena, in the north-west of Scotland (UK). Marine Ecology Progress Series 381, 297-310.

MOD (2011) Exercise Joint Warrior. Available at: http://www.royalnavy. mod.uk/Operations/Current-Operations/Operational-deployments/ Exercise-Joint-Warrior (accessed 16 August 2011).

Northridge S.P., Tasker M.L., Webb A. and Williams J.M. (1995) Distribution and relative abundance of harbour porpoises (Phocoena phocoena L.), white-beaked dolphins (Lagenorhynchus albirostris Gray), and minke whales (Balaenoptera acutorostrata Lacépède) around the British Isles. ICES Journal of Marine Science 52, 55-66.

Palka D. (1996) Effects of Beaufort sea state on the sightability of harbour porpoises in the Gulf of Maine. Report of the International Whaling Commission 46, 575-582.

Parsons E.C.M., Shrimpton J. and Evans P.G.H. (2000) Cetacean conservation in northwest Scotland: perceived threats to cetaceans. European Research on Cetaceans 13, 128-133.

Pierce G.J., Caldas M., Cedeira J., Santos B.M., Llavona Á., Covlea P., Martinez G., Torres J., Sacau M. and López A. (2010) Trends in cetacean sightings along the Galician coast, north-west Spain, 2003-2007, and inferences about cetacean habitat preferences. Journal of the Marine Biological Association of the United Kingdom 90, 1547-1560.

Pierce G.J., Santos M.B., Reid R.J., Patterson I.A.P. and Ross H.M. (2004) Diet of minke whales Balaenoptera acutorostrata in Scottish (UK) waters. Journal of the Marine Biological Association of the United Kingdom 84, 1241-1244. 
Pierpoint C., Allan E., Arnold H., Evans P., Perry S., Wilberforce E. and Baxter J. (2009) Monitoring important coastal sites for bottlenose dolphin in Cardigan Bay, UK. Journal of the Marine Biological Association of the United Kingdom 89, 1033-1043.

Pierpoint C. (2008) Harbour porpoise (Phocoena phocoena) foraging strategy at a high energy, near-shore site in south-west Wales, UK. Journal of the Marine Biological Association of the United Kingdom $88,1167-1173$

Reid J., Evans P. and Northridge S.P. (2003) Atlas of cetacean distribution in north-west European waters. JNCC report. Peterborough: Joint Nature Conservation Committee.

Robinson K.P., Tetley M.J. and Mitchelson-Jacob E.G. (2009) The distribution and habitat preference of coastally occurring minke whales (Balaenoptera acutorostrata) in the outer southern Moray Firth, northeast Scotland. Journal of Coastal Conservation 13, 39-48.

SCANS-II (2008) Small Cetaceans in the European Atlantic and North Sea (SCANS-II). Final report to the European Commission LIFE Nature programme on project LIFEo4NAT/GB/ooo245. Available at: biology.st-andrews.ac.uk/scans2/inner-finalReport.html (accessed 4 April 2013).

Stevick P.T. (2007) Evidence for why changes in minke whale prey off Scotland: why collaboration matters. In Robinson K.P., Stevick P.T and MacLeod C.D. (eds) An integrated approach to non-lethal research on minke whales in European waters. European Cetacean Society Special Publication Issue 47, pp. 8-13.

Stockin K.A., Weir C.R. and Pierce G.J. (2006) Examining the importance of Aberdeenshire (UK) coastal waters for North Sea bottlenose dolphins (Tursiops truncatus). Journal of the Marine Biological Association of the United Kingdom 86, 201-207.

Tetley M.J. (2010) Site fidelity, habitat preferences and coastal ecology of Atlantic minke whales (Balaenoptera acutorostrata). $\mathrm{PhD}$ thesis. University of Wales, Bangor, UK.

Tetley M.J., Mitchelson-Jacob E.G. and Robinson K.P. (2008) The summer distribution of coastal minke whales (Balaenoptera acutorostrata) in the southern outer Moray Firth, NE Scotland, in relation to co-occurring mesoscale oceanographic features. Remote Sensing of Environment 112, 3449-3454.

Thompson P.M., Tufft N.S., Grellier K. and Durban J.W. (2000) Evaluation of techniques for monitoring the abundance and behaviour of bottlenose dolphins-the Kessock channel as a case study. Scottish Natural Heritage Commissioned Report No. F99LEo1.

Weir C.R. (in press) Advice on developing a programme of survey work to underpin the selection of Marine Protected Areas for cetaceans in Scottish territorial waters. Scottish Natural Heritage commissioned research report.

Weir C.R. (2010) Cetaceans observed in the coastal waters of Namibe Province, Angola, during summer and winter 2008. Marine Biodiversity Records 3, e27 DOI: http://dx.doi.org/10.1017/ $\mathrm{S}_{1755267210000230}$

Weir C.R. (2008) Occurrence of the white-beaked dolphin (Lagenorhynchus albirostris) and other cetacean species in the Minch, August 2007. Scottish Natural Heritage Commissioned Report No.305, ROAME No. Fo5AC701.

Weir C.R., Stockin K.A. and Pierce G.J. (2007) Spatial and temporal trends in the distribution of harbour porpoises, white-beaked dolphins and minke whales off Aberdeenshire (UK), north-western North Sea Journal of the Marine Biological Association of the United Kingdom 87 , $327-338$.

and

Weir C.R., Pollock C., Cronin C. and Tasker M. (2001) Cetaceans of the Atlantic Frontier, north and west of Scotland. Continental Shelf Research 21, 1047-1071.

\section{Correspondence should be addressed to:}

S. Dolman

Whale and Dolphin Conservation Society, 38 St Paul Street Chippenham, Wiltshire SN15 1LJ, UK email: sarah.dolman@wdcs.org 